\title{
SMO (BOMO) SLOVENCI ZA TRG DELOVNE SILE NAROD PREVEČ IZOBRAŽENIH?
}

$N_{c}$ zgornje vprasanje bi vecina, se zlasi strokovnjaki, odgovorila »seveda ne, kvečjemu narod premalo izobraženih «. Saj nam vendar Evropska unija ves čas očita primanjkljaj ravno na področju izobraževanja, sploh izobraževanja odraslih. Toda, ko sem taisto vprašanje zastavila mladim do 26 let s končano fakulteto, so pritrdili, da delodajalci raje zaposlujejo ljudi s srednjo in višjo ali visoko šolo, manj pa ljudi z univerzitetno stopnjo izobrazbe.

Tisti, ki že dolgo niste povpraševali po novi zaposlitvi, si verjetno težko predstavljate, vendar se ne zgodi redko, da potencialni kandidati zamolčijo svojo dejansko izobrazbo. Predvsem zamolčijo magisterije in še bolj pogosto doktorate. Slednjih se je oprijel sloves teoretične usmerjenosti, ki je daleč stran od realnega poslovnega vrveža in tekme za obstanek ter konkuriranja na globalnih trgih. Še zlasti doktoratov iz družboslovnih ved. $\mathrm{Na}$ drugi strani pa primanjkuje tehničnih kadrov $s$ srednjo izobrazbo. Baje jih v Sloveniji preprosto ni moč dobiti in tako podjetja delovno silo že uvažajo iz držav jugovzhodne Evrope. Pa si oglejmo nekaj številk, ki so jih letos objavili na Zavodu za zaposlovanje.

Decembra leta 2005 je bila brezposelnost mladih med 15, in 24. letom starosti 16,2-odstotna, povprečje v Evropi je 18,4 odstotka. Največjo brezposelnost v tem obdobju si je neslavno priborila Poljska, kar 35-odstotno, najnižjo, 7-odstotno, pa Nizozemska. Ko si med mladimi brezposelnimi ogledamo izobrazbeno strukturo, lahko ugotovimo, da ima več brezposelnih VII. stopnjo izobrazbe kot VI. Tako je bilo konec leta 2005 med brezposelnimi mlajšimi osebami do 26 let s VII. stopnjo izobrazbe 815 brezposelnih, medtem ko jih je bilo med mladimi do 26 let $s$ VI. stopnjo izobrazbe le 222. Podobno razmerje ugotovimo ne le med mladimi, temveč med vsemi brezposelnimi. Tako je bilo konec lanskega leta vseh brezposelnih $s$ VII. stopnjo izobrazbe 5.186, medtem ko jih je bilo med tistimi s VI. stopnjo izobrazbe 2.232. Ta razlika je še posebej zanimiva. Ali potemtakem povprašujejo po kadrih s VI. stopnjo izobrazbe? Številke se namreč drastično dvignejo, ko pogledamo stanje brezposelnih s III., V. in VI. stopnjo izobrazbe. V. stopnjo izobrazbe ima kar 25.411 iskalcev zaposlitve, III. ali VI. stopnjo pa 22.565 iskalcev zaposlitve. Daleč največ pa je iskalcev zaposlitve s I. ali II. stopnjo izobrazbe, kar 37.181 .

So torej mladi in izobraženi žrtve "zlobnega" trga dela? Podatki vsekakor pričajo o tem, da je trg dela podvržen medgeneracijskim in izobraževalnim pritiskom. Višja stopnja izobrazbe trenutno negativno vpliva na možnost zaposlitve mladih. Zagotovo $k$ temu dodatno pripomore tudi delovna zakonodaja, ki je preko vseh meja obdavčila delo, še zlasti delo izobražencev oz. tistih z višjimi osebnimi dohodki. Novela zakona o delovnih razmerjih obljublja, da bo davek na izplačane plače ukinila in tako dodatno spodbudila zaposlovanje mladih z visoko izobrazbo. Toda dokler se to ne bo zgodilo, bodo morali mladi izobraženci še naprej krmariti med Scilo in Karibdo, 
torej med potrebami podjetij po inovativnih rešitvah in med njim nenaklonjeno delovnosocialno zakonodajo. Z obljubami se namreč ne da (pre)živeti.

Na podlagi predstavljenih številk lahko naredimo določen sklep, in sicer da je izobrazba zagotovo pomemben element socialne mobilnosti, toda le do določene meje. Ta hip se zdi, se je meja zaustavila na VI. stopnji izobrazbe. Doktorate in magisterije je očitno ta hip pametneje zamolčati, če želimo dobiti službo. Se podjetja bojijo intelektualcev, češ, teoretikov ne potrebujemo, ali je razlog le $v$ velikih stroških dela ljudi s VII., VIII. in IX. stopnjo izobrazbe?

Izobraževanje po programih bolonjske deklaracije bo na že tako občutljiv trg dela vneslo nove dimenzije. Pričakovati je, da se bo veliko ljudi, ki imajo končano VII. stopnjo izobrazbe, odpravilo nazaj v šolske klopi in v letu dni pridobilo tisto, kar menijo, da jim že tako pripada po starem načinu študija v primerjavi z novim, po magistrsko diplomo. Delodajalci že danes svarijo, da zaradi tega ne bodo imeli nič višje plače, niti jim ne bodo plačali študija. Zna se zgoditi, da bo kdo celo ostal brez službe zato, ker si je priboril višjo stopnjo izobrazbe - kako paradoksalno. Morda se tudi menedžerji bojijo, da bi jih utegnil kdo ogroziti na položaju. Toda ljudje smo pač takšni, da želimo rasti in se razvijati, zato bomo izobraževanje plačali iz lasinega žepa.

In tukaj se zgodba šele zares pričenja. Liberalizacija visokega šolstva, ki očitno posega že na področje srednjega in osnovnega šolstva, je tukaj. Medtem ko večina univerz z zavidljivo tradicijo še premleva kakovost izobraževalnih programov in si želi izboriti pogoje $z$ a poseben status predmetov in enovit študij (primer medicina), vsenaokrog po Sloveniji rastejo nove visoke sole in tudi fakultete po bolonjskem programu $3+2$, ki so večinoma $v$ zasebni lasti in veselo vabijo študente ter jim obljubljajo lažjo pot do uspeha. In verjeli ali ne, nekatere tudi že zapirajo vrata novincem.
Jihje preveč, pravijo. Kaj si torej študentje zares lahko obetajo od bolonjskih programov? Predvsem časovno krajšs študij in morebiti kje tudi lažjo pot do diplome, še posebej, če bodo morali šolnino sami plačati. Zaskrbljujoča je predvsem hitra rast zasebnih fakultet, nekatere izmed njih si bodo lahko zagotovile vpis le na način, da bodo že ob vpisu obljubile diplomo. Torej priznale posamezniku znanje, ki ga dejansko nina. Da se to dogaja tudi v javnem šlskem sistemu, ni nobena skrivnost. Danes ze vsak gimnazijec ve, da je vreden približno 1,200.000 tolarjev na leto, prav tako pa $v$ poklicnih šolah znajo izračunati, da so za solo vredni dobrih 700.000 tolarjev na leto. Če torej ne naredijo letnika, bo šla ob omenjeno vsoto denarja. Tega se zavedajo tudi ucitelji, ki sprico neverjetnih pravic učencev že tako stežka krmarijo ned Scilo in Karibdo. $\breve{C}$ e drugo leto ne bo zadostnega števila otrok $v$ šolah, so lahko celo ob službo.

In kaj si lahko obetajo podjetja od bolonjskih programov? Verjetno malo manj zrele posameznike, ki jih bodo zato nekoliko laže prilagodila sebi in svojim potrebam. Navsezadnje pa imajo krasno možnost, da ustanovijo tudi svoje fakultete in dobijo točno to, kar si žetijo. $\breve{C}$ e se seveda računica izide. Tako ali drugače bodo morala več vlagati v vseživljenjsko izobraževanje.

Morda je ta pot preprosto potrebna, da bomo spoznali resnično vrednost kakovostne izobrazbe. Saj živimo v družbi znanja, mar ne?

Dr. Daniela Brečko 